\title{
A CONTRIBUTION TO THE EXPERIMENTAL STUDY OF THE ALLERGIC PROCESSES OF THE ANTERIOR SEGMENT OF THE EYE*
}

BY

\section{A. KECKAROVSKI}

From the Eye Clinic of the Medical Faculty of the University of Skopje, Yugoslavia

In order to observe local anaphylactic processes caused by the injection of antigenic substances into the anterior segment of the eye, a series of experiments on 108 rabbits was undertaken, using human, horse, pig, and ox sera as antigens. Each series consisted of six to twelve animals, and included control groups when needed.

\section{Procedure}

The injections were made with the animals under general anaesthesia (about 40 mg. "Nesdonal" per $\mathrm{kg}$. body weight).

(1) With the eye rotated downwards by pulling the superior rectus muscle, the needle was inserted obliquely into the central area of the cornea and 0.1 ml. antigen was injected.

(2) The needle was inserted obliquely through the conjunctiva about $2 \mathrm{~mm}$. from the limbus until it appeared in the anterior chamber; the aqueous was then allowed to drain off, and $0.1 \mathrm{ml}$. antigen was injected.

\section{Results}

These are given in Table I; 28 animals underwent a double sensitization of both cornea and uvea in the same eye with the same antigen. The results are analysed by site in Table II, and the antigens used are shown in Table III.

The injection of antigen into the eye was immediately followed by a traumatic reaction (oedema of the cornea, iris congestion, and sometimes a little exudation) which disappeared completely within a few hours. Control animals, in which one eye was sensitized and the other was injected with a 1 per thousand dilution of "Sunoxol", a preservative used in the sera, showed a similar traumatic reaction in both eyes, which was due to the fluid introduced. The eyes which were given "Sunoxol" only showed no other reaction either primary or secondary.

Some of the results are illustrated graphically in Figs 1 to 3 (overleaf), which show the height and duration of the reactions.

The "height" of the corneal reaction was judged arbitrarily in degrees of transparency:

(i) Slight cloudiness;

(ii) Intermediate;

(iii) Total opacity. 
TABLE I

ANALYSIS OF RESULTS

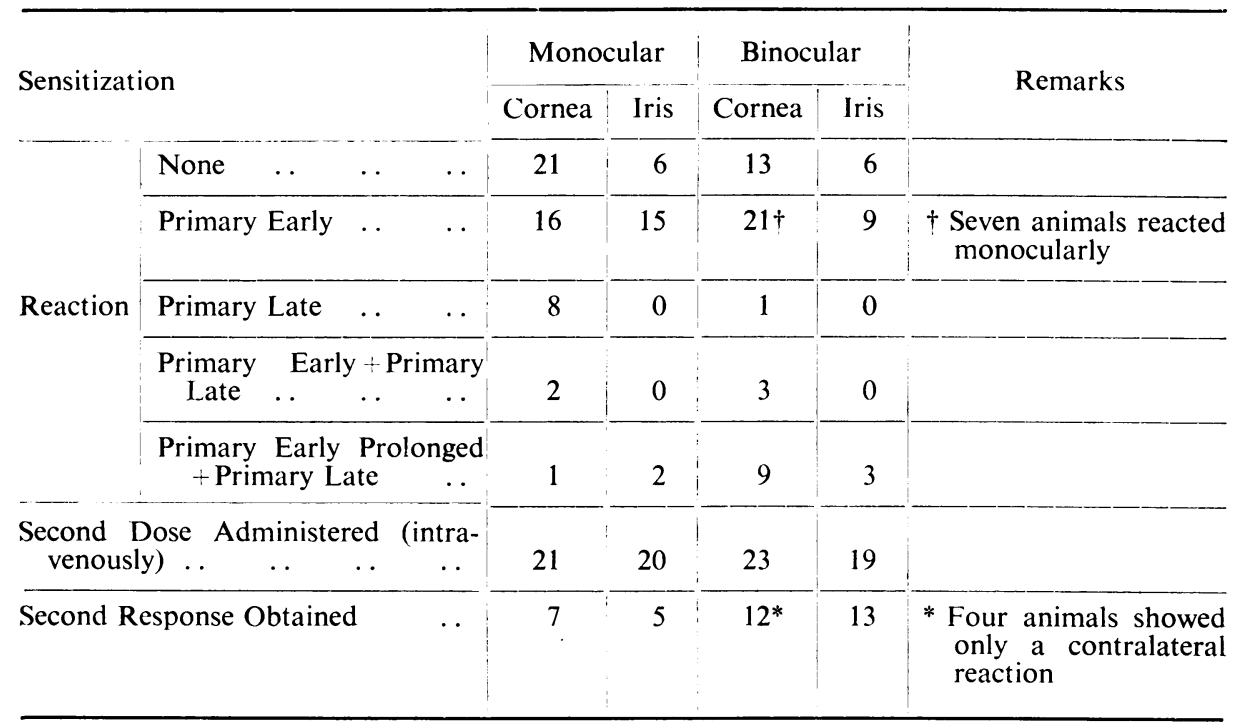

TABLE II

RESULTS ANALYSED ACCORDING TO SITES OF REACTIONS IN THE SAME EYE

\begin{tabular}{l|l|c|c|c|c}
\hline \multirow{3}{*}{ Reaction } & Primary & Present & Present & Absent & Absent \\
\cline { 2 - 7 } & Secondary & Present & Absent & Present & Absent \\
\hline \multirow{2}{*}{ Site } & Cornea & 15 & 12 & 4 & 13 \\
\cline { 2 - 6 } & Iris & 16 & 11 & 2 & 10 \\
\hline
\end{tabular}

TABLE III

RESULTS ANALYSED ACCORDING TO SITES OF REACTIONS TO DIFFERENT SERA

\begin{tabular}{|c|c|c|c|c|c|c|c|c|c|c|}
\hline \multirow{2}{*}{\multicolumn{2}{|c|}{ Serum Used as }} & \multirow[t]{2}{*}{ Antigen } & \multicolumn{2}{|c|}{ Site } & \multicolumn{2}{|c|}{$\begin{array}{l}\text { Primary } \\
\text { Response }\end{array}$} & \multicolumn{2}{|c|}{$\begin{array}{l}\text { Second Dose } \\
\text { Administered }\end{array}$} & \multicolumn{2}{|c|}{$\begin{array}{l}\text { Second Response } \\
\text { Obtained }\end{array}$} \\
\hline & & & Cornea & Iris & Cornea & Iris & Cornea & Iris & Cornea & Iris \\
\hline $\begin{array}{l}\text { Human } \\
\text { Horse } \\
\text { Ox } \\
\text { Pig } \\
\end{array}$ & $\begin{array}{l}\ldots \\
\cdots \\
\cdots \\
\cdots\end{array}$ & $\begin{array}{l}\ldots \\
\cdots \\
\cdots \\
\cdots\end{array}$ & $\begin{array}{r}37 \\
22 \\
65 \\
7 \\
\end{array}$ & $\begin{array}{l}12 \\
13 \\
35\end{array}$ & $\begin{array}{r}25 \\
12 \\
48 \\
5\end{array}$ & $\begin{array}{r}12 \\
7 \\
25\end{array}$ & $\begin{array}{r}19 \\
14 \\
24 \\
7 \\
\end{array}$ & $\begin{array}{r}9 \\
8 \\
21\end{array}$ & $\begin{array}{r}12 \\
8 \\
6 \\
2 \\
\end{array}$ & $\begin{array}{r}3 \\
4 \\
10\end{array}$ \\
\hline \multicolumn{3}{|c|}{ Total } & 131 & 60 & & & & & & \\
\hline
\end{tabular}

The "height" of the reaction in the anterior uvea was judged as follows:

(i) Congestion of the iris, miosis, and a little exudation;

(ii) Iris oedema and haemorrhages with exudation;

(iii) Marked exudation with synechiae. 


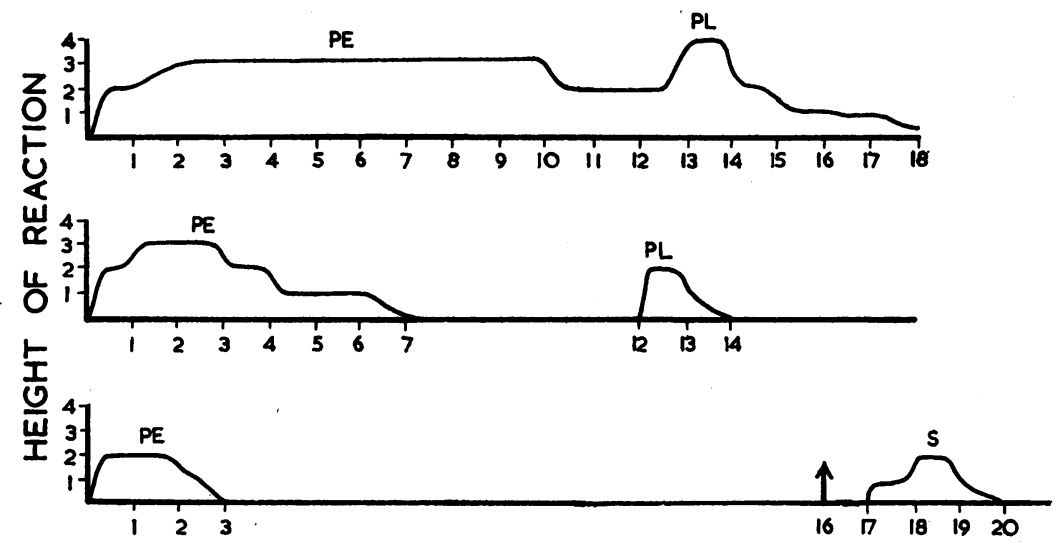

(b)

TIME (days)

FIG. 1.-Unilateral sensitization of cornea.

$\mathrm{PE}=$ Primary early. $\mathrm{PL}=$ Primary late. $\mathrm{S}=$ Secondary.

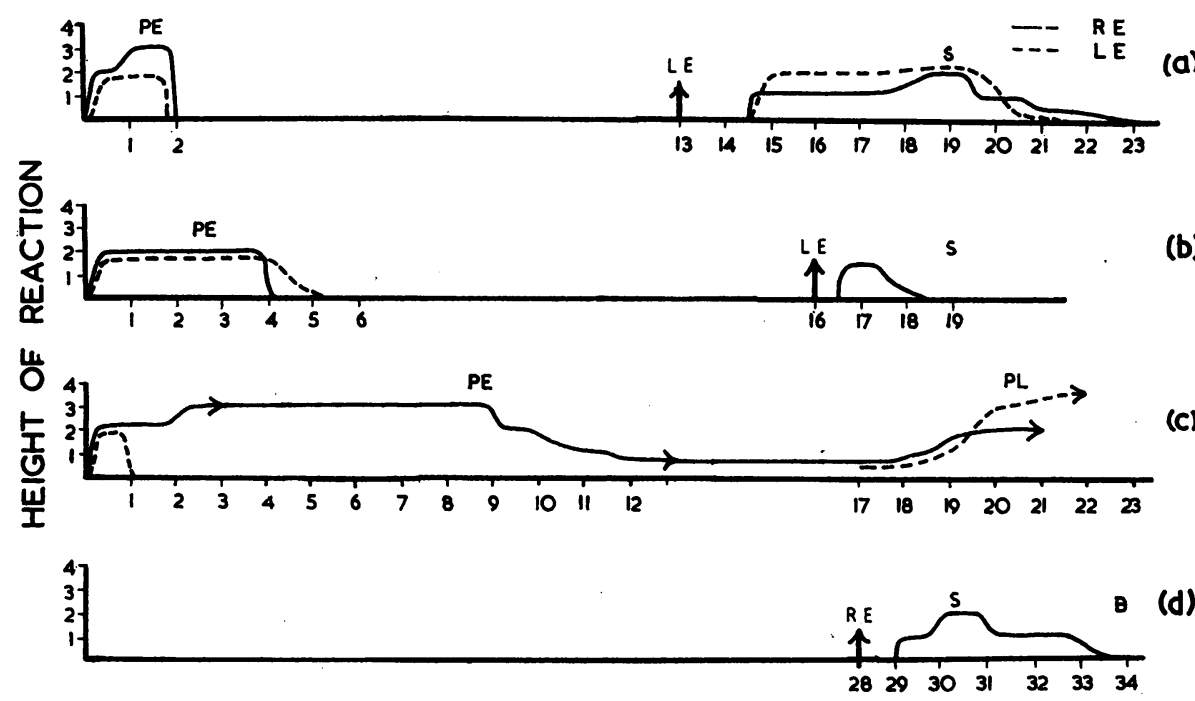

TIME (days) FIG. 2.-Bilateral sensitization of cornea.

$\mathbf{P E}=$ Primary early. $\quad \mathbf{P L}=$ Primary late. $\mathrm{S}=$ Secondary .

About sixty animals were given a different antigen into each eye as the primary dose, and in these cases the results are represented on the graphs by full and dotted lines.

The prolonged type of primary early reaction (Figs $1 a, 3 b$, and $3 c$ ) was seen in fifteen instances, and was followed by a late reaction in each case. In bilaterally-sensitized animals, the primary late reaction, when it appeared, occurred in both eyes.

Second Doses. - In each Figure, arrows indicate the intravenous administration of a second dose of 2-3 ml. antigen, and above the arrows is shown the eye which had already been sensitized to the same antigen. 

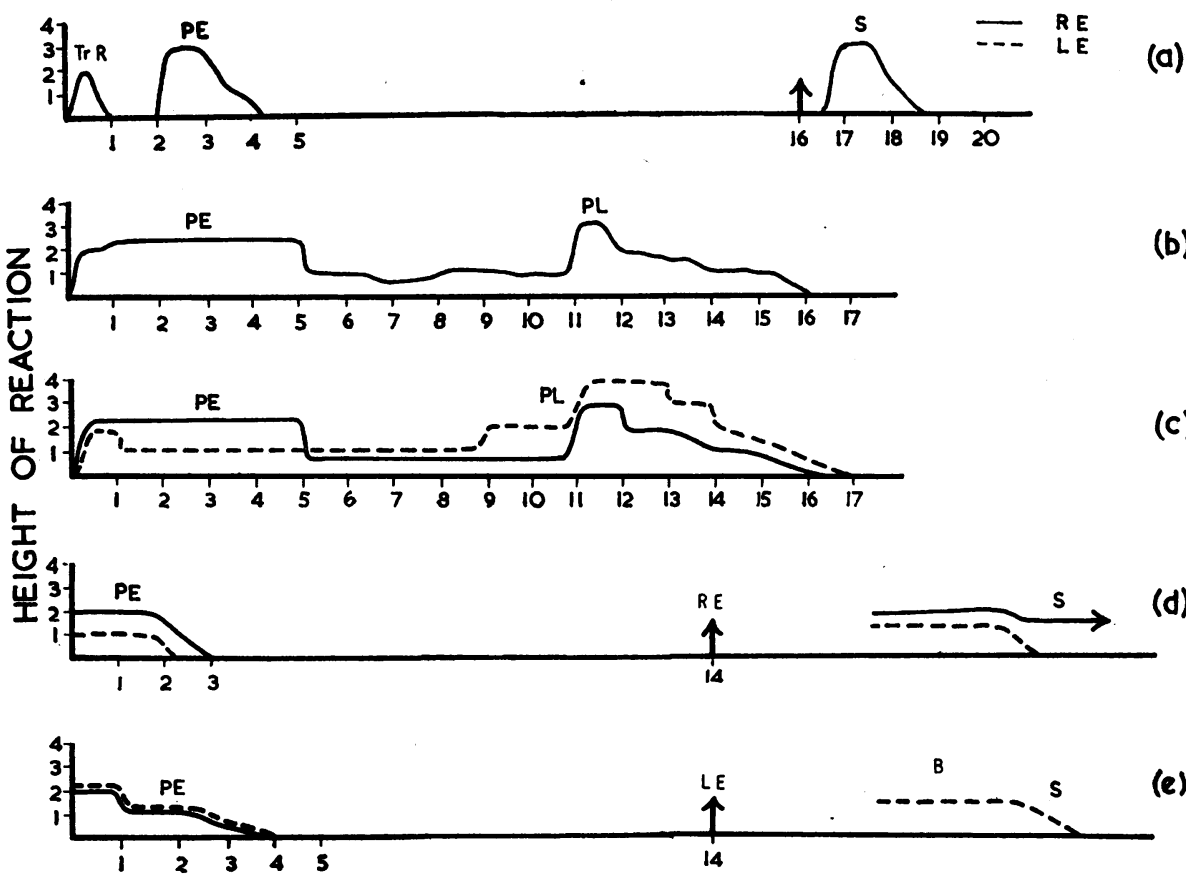

TIME (days)

Fig. 3.-Unilateral and bilateral sensitization of iris.

$\mathrm{PE}=$ Primary early. $\mathrm{PL}=$ Primary late. $\mathrm{S}=$ Secondary .

The binocularly-sensitized animals were given as a second dose only one of the antigens previously used. In all cases which reacted to the second dose, a contralateral, non-specific response was also obtained. Four animals in which the two corneae had been sensitized to different sera, showed only a contralateral response, the eye which had already been sensitized to the antigen used for the second dose remaining quiet. The control animals, which were given as a second dose a serum other than those used for the first sensitizing injection, did not react at all (these included eight animals which had been given human or ox serum, sheep serum being used for the "anaphylactic" dose).

Effects of Blockading the Eyes.-A series of nine animals which had been binocularly sensitized in both the cornea and the uvea (the right eye with human serum, and the left with ox serum) received a second dose (of human serum only) on the 28th day after the first injection. Just before the second injection, four of them received bilaterally a "blockading" retrobulbar injection of $2 \mathrm{ml}$. absolute alcohol and 4 per cent. Novocain in equal amounts. The corneae of only three animals reacted: two which had been blockaded and one which had not. The uveae of four animals reacted: the 
same three in which the corneae had reacted, and one other which had been blockaded. The one reactor (cornea and iris) which had not been blockaded showed a bilateral response, and the three reactors which had been blockaded (two corneae and three irides) showed only a monocular response. In these three reactors, only the right eye, which had previously been sensitized to the same serum, reacted, while the left eye, which had previously been sensitized to a different serum, remained quiet.

Of a series of six animals, in which the anterior uvea had been sensitized in both eyes (one to human and the other to ox serum), three were blockaded by retrobulbar injections, and all were given a second intravenous dose of one of the antigens used in the first injections. One blockaded animal died under general anaphylactic shock, and the other two reacted monocularly. One which had not been blockaded did not react at all, and the other two reacted bilaterally. Here again, only those blockaded eyes reacted which had previously been sensitized to the antigen used for the second dose. The effects in two blockaded cases are illustrated in Figs $2(d)$ and $3(e)$.

\section{Discussion}

Two types of primary response may occur. These are easily distinguished when they occur in the cornea. The early type appears at the site of injection within a few days, spreads toward the limbus but does not always reach it, and is more marked centrally, its intensity decreasing toward the periphery. The late type appears some 10 days after the local injection, starting from the limbal region in the form of a whitish-grey ring, and progressing to the centre of the cornea; a dense network of blood vessels arranged concentrically like a wreath arises from the limbal plexus (Fig 4, opposite). Both types of response may occur successively, or one or both may fail to appear.

The secondary response, when elicited, has the same clinical features as the primary late response.

The following facts are to be noted:

(1) A primary early reaction, when marked and prolonged, was always followed by a late one.

(2) In binocularly sensitized animals, the primary late reaction, when it appeared, was bilateral.

(3) Nearly all binocularly sensitized animals which reacted to the second (intravenous) dose, did so bilaterally, although only one of the original antigens was re-introduced.

(4) Sometimes the processes appeared in each eye successively. The specific secondary responses were the first to appear.

These observations suggest the existence of a relationship between the parallel processes in the two eyes, and indicate that a process in one eye can set going or contribute towards a similar process in the other eye. The secondary specific process may result from an interaction between some residual antigen stored in the cornea and the circulating antibodies, the production of which has been stimulated by the second dose. It may also result from 


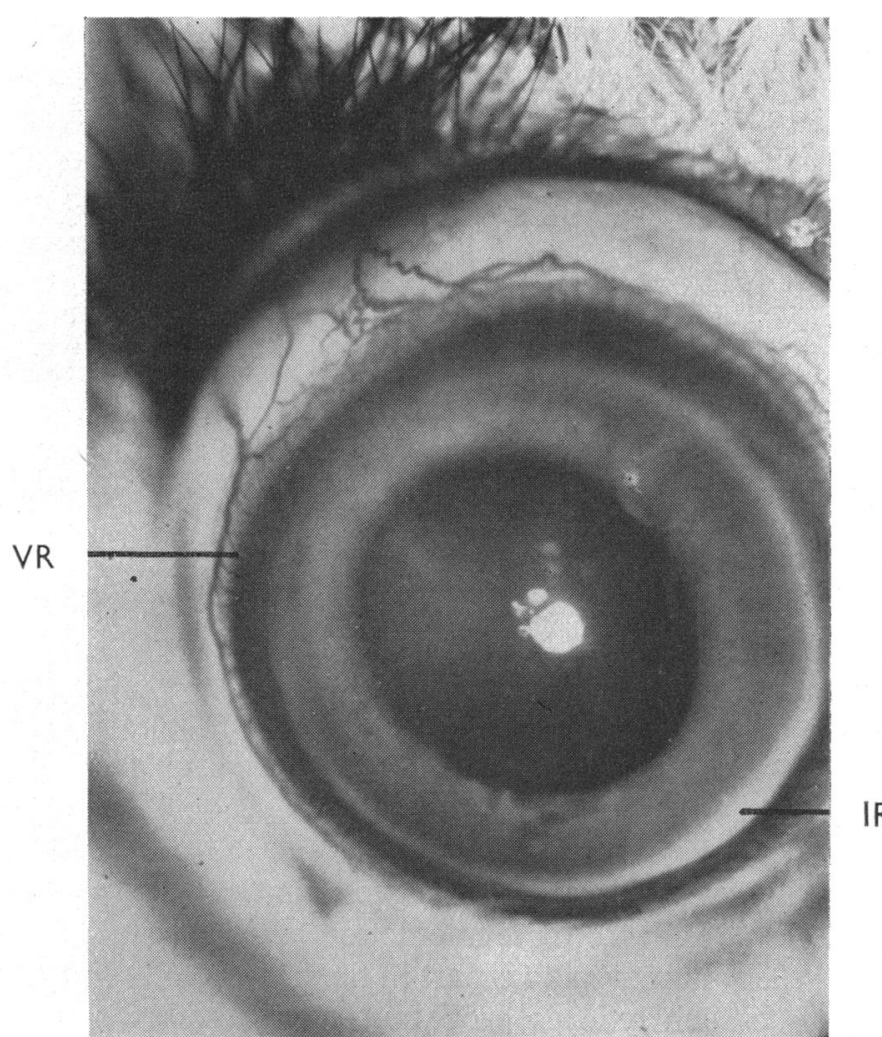

Fig. 4.-Primary late reaction of cornea.

$\mathrm{VR}=$ Vascular ring.

$\mathrm{IR}=$ Infiltration ring.

direct contact between the re-injected antigen and the reactive agents already stored in the corneal tissue. This latter course is the more likely, as it does not seem very probable that a residual antigen will persist in the corneal tissue, especially after repeated secondary responses. The contralateral, non-specific effect could also perhaps be explained by an analogous humoral mechanism, the production of antibodies being also stimulated in the fellow eye (by an anamnestic reaction).

This explanation seems insufficient, however, to account for the results in the blockaded cases; the specific response could not be influenced by the retrobulbar injection, and the contralateral response was invariably prevented by it. The blockade could not have influenced the humoral relations of the two eyes, for the second dose of antigen had the same chance of reaching both eyes as the antibodies the production of which had been stimulated by the second dose.

The blockade may, however, influence the neuro-reflex relationship between the two eyes, and the results obtained in these experiments indicate the existence of a reflex factor in the allergic processes of the eye. 
In four animals a contralateral effect was obtained only after the second dose; the eye which had already been sensitized to the antigen used for the second dose did not react, but its fellow did (Fig. 2b). This may be due to an "elective sensitization" of tissues (Føss, 1949). The absence of response in the first eye might be due to a decreased level of concentration of the corresponding antibodies. The supposed increased in the antibodies in the fellow eye might be responsible for its non-specific response. If this explanation is correct, it should also be applicable to the cases which reacted bilaterally, but in these the contralateral reaction was prevented by the blockade. If the reflex mechanism does play a part in this contralateral response, even in the absence of a specific response in the fellow eye, one must admit the existence of a source of the reflexes which seem to be responsible for this non-specific reaction.

\section{Conclusions}

(1) The primary early reaction in sensitized eyes, when marked and prolonged, is always followed by a late reaction.

(2) In animals sensitized with a different antigen in each eye, a marked and prolonged primary early reaction, even in one eye only, is followed by a bilateral late reaction.

(3) The results of these experiments suggest that the allergic processes of the eye do not always result from the interaction of the humoral elements, but that neuro-reflex factors may play a part in the genesis of contralateral, nonspecific responses. Such reflexes probably originate from the pre-existing process in the fellow eye. In principle, this idea may be extended to cover analogous reactions between the eyes and any focal process elsewhere, or even between any two organs.

(4) The occurrence, though rare, of a contralateral, non-specific reaction in the absence of a specific reaction in the fellow eye, suggests that even an apparently normal unaffected eye may evoke pathogenic impulses in the other eye.

These experiments were mainly carried out at the Ophthalmic Clinic of the Medical Faculty at Nantes, France, in 1956. The Principal at the time, the late Prof. G. P. Sourdille, arranged for my work to be carried out under the most favourable conditions. He and his successor, Prof. J. Legrand took a great interest in my work, giving me their best advice. I should like to express my most cordial appreciation for all this help, and also that of Dr. Hervouert, head of the Clinic laboratory, who assisted me personally and ensured the availability of all the facilities of the laboratory, and of M. A. Lenoir, who gave technical help and was responsible for the photography and histopathological preparations.

\section{REFERENCES}

Føss, B. (1949). “Experimental Anaphylactic Iridocyclitis”, Acta path. microbiol. scand., Suppl. 81.

SzILY, A. von (1914). v. Graefes Arch. Ophthal., 88, 195.

WeSSELY, K. (1911). Münch. med. Wschr., 58, 1713. 


\section{SELECT BIBLIOGRAPHY}

Berens, C., Sayad, W. Y., and Girard, L. J. (1952). Trans. Amer. Acad. Ophthal. Otolaryng., $56,220$.

Dold, H., and Rados, A. (1913). Dtsch. med. Wschr., 39, 1492, 2254.

DonegaN, J. M. (1955). Ann. Allergy, 13, 559.

DugGan, W. F. (1946). Arch. Ophthal. (Chicago), 36, 551

DUKE-ELDER, S. (1938). "Text-book of Ophthalmology", vol. 2, p. $1455 . \quad$ Kimpton, London.

D'ERmo, F. (1950). Boll. Ocul., 29, 681.

FRIEDENWALD, J. (1934). Amer. J. Ophthal., 17, 1008.

HANSER, S. A. (1955). Trans. Amer. Acad. Ophthal. Otolaryng., 59, 480.

IGERSHEIME, J. (1913). v. Graefes Arch. Ophthal., 85, 361.

LöWenstein, A. (1938). Klin. Mbl. Augenheilk., 101, 432.

LemoIne, A. N. (1942). Arch. Ophthal. (Chicago), $28,79$.

MAGITOT, A. (1927). Ann. Oculist. (Paris), 164, 897. (1928). Ibid., 165, 1.

MorawIECKI, J. (1956). XXV Zjazd Okulistow Polskich, Lublin (koreferat).

PAYNE, B. F. (1953). Trans. Amer. Acad. Ophthal. Otolaryng., 57, 468.

Pelouze, P. S. (1932). Arch. Ophthal. (Chicago), 7, 372.

SCHEFFLER, M. M. (1953). Amer. J. Ophthal., 36, 1449.

SteINBüGLER, W. F. C. (1930). Arch. Ophthal. (Chicago), 4, 220.

TOPLEY, W. W. C., and WILSON, G. S. (1946). "Principles of Bacteriology and Immunity", 3rd ed., rev. G. S. Wilson and A. A. Miles, pp. 1075-1188. Arnold, London.

Thompson, R., and OLSON, H. (1950). J. Immunol., 65, 633.

TASSMAN, I. S. (1950). "The Eye Manifestations of Internal Diseases", 3rd ed., chaps 9 and 13. Kimpton, London. 